Alina Kalinowska

https://doi.org/10.26881/pwe.2019.47.07

ORCID: 0000-0003-4658-7620

Uniwersytet Warmińsko-Mazurki w Olsztynie

alina.kalinowska@uwm.edu.pl

\title{
Zjawisko ukrytej przemocy wobec najmłodszych uczniów na zajęciach matematycznych
}

\begin{abstract}
Summary
The phenomenon of hidden violence against the youngest students in math classes

The paper undertakes research meant to identify the teacher's violent behaviour towards students during early school math lessons. The research conducted in grade one during the math class was used as an aid to deeper understanding of the phenomenon of violence in school. It was found that some lesson procedures, mathematical formulations, and cognitive situations can be seen from the perspective of teacher violence. Their effects can reduce pupils' self-esteem, limit understanding of mathematics and hinder full participation in culture now and in the future.
\end{abstract}

Keywords: early childhood mathematical education, hidden violence, teacher, student

Słowa kluczowe: wczesnoszkolna edukacja matematyczna, ukryta przemoc, nauczyciel, uczeń

\section{Wstęp}

Przemoc jest zjawiskiem obszernie opisanym w literaturze. Pojawiające się definicje można podzielić ze względu na trzy główne kryteria: sposoby zachowania się sprawcy, intencje oraz konsekwencje działań przemocowych dotykające ofiary (Rode 2010: 19). Sposoby myślenia o przemocy koncentrują się nie tylko na wymuszaniu określonych zachowań jednostki, ale także na jej sposobie myślenia i postrzegania rzeczywistości (Koczara 1997: 11). W potocznym rozumieniu określenie „przemoc” jest najczęściej używane do opisywania agresji fizycznej przeciwko jednej osobie lub grupie ludzi. Według Johanny Ruge określenie ,przemoc emocjonalna lub psychiczna” opisuje inne rodzaje zachowań, które nie szkodzą bezpośrednio ciału fizycznemu, ale jeszcze bardziej zasługują na miano „przemocy” ze względu na negatywny wpływ na jakość życia danej osoby (Ruge 2018). Również w definicji Światowej Organizacji Zdrowia (WHO - World Health Organization) zwraca się uwagę na aspekt psychiczny, określając przemoc jako ,użycie z rozmysłem siły lub grożenie nią, przeciw sobie, innej osobie, grupie lub społeczności, co prowadzi do zranienia, śmierci, lub szkody psychicznej, a także do zaburzeń rozwojowych i upośledzenia społecznego" (Krug i in. 2002: 5). 
Zbigniew Kwieciński ujmuje za Bourdieu zjawisko przemocy w dwa rodzaje, zróżnicowane poziomem świadomości podmiotu. W pierwszym przemoc jest osobista, odczuwana przez jednostkę, a więc jawna. Może przyjąć postać agresji fizycznej, opresji psychicznej lub konieczności podporządkowania się innemu podmiotowi dla zaspokojenia podstawowych potrzeb. Drugi rodzaj to przemoc ukryta, nieuświadamiana przez podmiot, ale doświadczana w postaci „użycia przeważającej nad nim siły w celu podporządkowania jego świadomości, sposobu oceniania zdarzeń, ludzi, relacji (...) tak, by przyjmował je jako naturalne, oczywiste i dlatego usprawiedliwione" (Kwieciński 1995: 125). W konsekwencji autor rozróżnia przemoc symboliczną - narzucanie znaczeń i symboli kultury, oraz strukturalną - przemoc „zastanych struktur świata” (Kwieciński 1995: 126). Dla Pierre'a Bourdieu każda czynność pedagogiczna, rozumiana jako transmisyjne narzucanie i wdrażanie, jest przemocą symboliczną, którą uzasadnia autorytet pedagogiczny, postrzegany jako władza. Wszelka „władza przemocy symbolicznej (tzn. każda władza, której udaje się narzucać znaczenia jako prawomocne) ukrywając stosunki siły, które są podstawą jej mocy, dorzuca swoją własną siłę (tzn. siłę czysto symboliczną) do tych stosunków siły" (cyt. za: Sawisz 1989: 70).

Wśród najbardziej istotnych mechanizmów przemocy symbolicznej w edukacji wskazuje się kod językowy, ponieważ uczestnicy komunikacji szkolnej zajmują ,,asymetryczne pozycje w dystrybucji odpowiedniego kapitału językowego" (Bourdieu, Wacquant 2001: 136). W instytucjach edukacyjnych można dostrzegać przemoc symboliczną w aktach językowych, ale również w aktach kinetycznych, oceniania dzieci, sposobie zagospodarowania przestrzeni oraz strategiach pracy (Falkiewicz-Szult 2007: 61).

Przemocowe konteksty matematyczne towarzyszą nam w wielu (czasem nieoczekiwanych) aspektach naszego życia. Nie zawsze bowiem zdajemy sobie sprawę z faktu, że wiele procesów w naszej rzeczywistości, jak obliczanie zdolności kredytowej, wyniki w pracy, ocena pracowników, możliwość uzyskania warunkowego zwolnienia dla więźniów i wiele innych, jest wyznaczanych przez algorytmy matematyczne, w których założenia są czasem przyjmowane a priori i bez wsparcia obiektywnych badań. Takie algorytmy mogą stanowić źródło dyskryminacji poszczególnych grup społecznych zwiększające nierówności społeczne, a nawet niszczące życie jednostek. Cathy O’Neil nazywa takie algorytmy Beemzetami, czyli bronia matematycznej zagłady (O’Neil 2017). Przemoc społeczna kreowana przez wiele modeli matematycznych wynika bezpośrednio z procesu ich zastosowania, w którym brane są pod uwagę przede wszystkim zyski właścicieli. Ponadto często nie podlegają one weryfikacji, ponieważ w wielu przypadkach (statystycznie) działają poprawnie. Autorka pokazuje wiele przykładów zastosowania wytworzonych przez matematyków Beemzetów, które obliczają prawdopodobieństwo jakiegoś zjawiska. Niestety, w wypadku poszczególnych osób może być ono zupełnie nieprawdziwe, choć urzeczywistnia się w niekorzystnej dla jednostki punktacji (O’Neil 2017).

Edukacja matematyczna jest związana z odtwarzaniem różnic społecznych w odniesieniu do mniejszości etnicznych, uczniów z ubogich środowisk oraz kobiet (Kopciewicz 2012: 33). Grupy te podlegają dyskryminacji edukacyjnej i są narażone na 
marginalizowanie kulturowe. Podobne mogą być skutki bezmyślności matematycznej określone przez Dorotę Klus-Stańską i Alinę Kalinowską (2004: 17) jako brak możliwości wyjścia poza wyuczone techniki rachunkowe w połączeniu z niezdolnością do tworzenia własnych strategii. Tym samym może skutkować proces uczenia się matematyki, który ogranicza rozumienie zagadnień matematycznych i w konsekwencji - zubaża możliwość uczestniczenia w kulturze.

O przemocy w szkole mówi się i bada ją przede wszystkim w relacjach uczeń-uczeń. Rzadziej dostrzega się przemocowy charakter procesu edukacji transmisyjnej w relacji nauczyciel-uczeń. $Z$ założenia przyjmujemy bowiem, że działania nauczyciela mają na celu dobro dziecka. Tymczasem, zdaniem Józefy Bałachowicz, indywidualny system przekonań nauczyciela jest bezpośrednio źródłem jego opinii, zachowań i działań edukacyjnych. Często jednak potoczne koncepcje nauczycieli mają konotacje behawiorystyczne, niedoceniające możliwości poznawczych dzieci. Jednocześnie z perspektywy najmłodszych uczniów niezwykle istotne jest doświadczanie podmiotowej aktywności jako istotnego budulca sposobu postrzegania samego siebie i świata oraz ich wzajemnych relacji. To właśnie „poczucie bycia podmiotem, refleksja nad działaniem i ocena własnej skuteczności są podstawą budowania przeświadczenia o sobie jako sprawcy odpowiedzialnych czynów w świecie, kreowania siebie i swojego miejsca w świecie" (Bałachowicz 2017: 56). Podczas gdy spędzony w klasach początkowych czas może być polem wielu (zbyt wielu) doświadczeń przemocowych ze strony dorosłych - tu: nauczyciela; nawet jeśli nie są tak nagłaśnianie jak agresja, to wymagają rozpoznania. Autorzy raportu z badań przeprowadzonych w Chinach, Indonezji oraz Rwandzie, a dotyczących przemocy wobec dzieci, przekonują, że nauczyciele, rodzice i dzieci muszą zrozumieć, że nie ma aktu przemocy zbyt małego do jego monitorowania i wygaszania (Lundin, Wesslund 2016: 22).

Być może warto więc przyjrzeć się specyfice edukacji matematycznej z perspektywy zjawiska ukrytej przemocy. Uczenie się matematyki w szkole jest już legendarnym źródłem traumatycznych doświadczeń młodych ludzi. Przez wielu z nich istnienie tego przedmiotu i konieczność zdawania egzaminu maturalnego są postrzegane jako forma przemocy decydentów edukacyjnych w kraju wobec uczniów. Potoczne opinie wyrażane publicznie na wielu forach internetowych mówią o braku związku matematyki, szczególnie z klas starszych, z możliwością wykorzystania tej wiedzy w rzeczywistości pozaszkolnej.

W wielu analizach teoretycznych zakłada się, że już wczesnoszkolna edukacja matematyczna powinna być inspirującym okresem poznawczym, w którym uczeń nabywa pewne kompetencje intelektualne niezbędne do rozwijania myślenia matematycznego (por. Dąbrowski 2008; Sfard 2008; Kalinowska 2010; Klus-Stańska, Nowicka 2014; Boaler 2016). Wśród nich najważniejsze wiążą się z umiejętnością samodzielnego konstruowania pojęć matematycznych dzięki prowadzeniu badań, odkrywaniu zależności i komunikowaniu się. Najczęściej jednak jest to czas budowania kompetencji odtwórczych (Dąbrowski 2009), głównie polegających na wyćwiczeniu umiejętności rachunkowych oraz rozwiązywaniu typowych zadań. 


\section{Założenia metodologiczne}

Badania umiejscowiono w paradygmacie interpretatywnym, traktując je jako próbę uporządkowania rzeczywistości za pomocą kategorii (Konecko 2000: 21). Do rozpoznania zjawiska ukrytej przemocy nauczycielskiej wybrano instrumentalne studium przypadku, które, jak podkreśla Krzysztof Tomasz Konecko: „nie jest wyborem metodologicznym, jest natomiast wyborem przedmiotu badania" (Konecko 2000: 126). Ta forma badania nie jest bowiem definiowana jako metoda gromadzenia danych, ale jest określana przez chęć rozpoznania danego zjawiska (Stake 2009: 623).

Robert Stake wymienia trzy rodzaje studium przypadku: autoteliczne, zbiorowe i instrumentalne (Stake 2009). Ten ostatni określa jako możliwość głębszego zrozumienia interesującego problemu, w którym opisywany przypadek pełni jedynie pomocniczą funkcję, został jednak wybrany ze względu na jego potencjał dla zrozumienia innego zjawiska (Stake 2009: 627).

Przedmiotem badań opisanych $\mathrm{w}$ tym tekście jest zjawisko nauczycielskiej przemocy wobec najmłodszych uczniów. Analizie poddano działania nauczycielki podczas jednej (trwającej 45 minut) pokazowej lekcji matematyki w klasie pierwszej, która odbyła się w październiku 2018 r. Oprócz autorki tego tekstu obecne na niej były studentki wczesnej edukacji. Celem podjętych badań było szukanie ewentualnych przejawów ukrytej przemocy na lekcji matematyki na poziomie wczesnoszkolnym oraz podjęcie próby interpretacji ich skutków. Jako technikę badań wybrano obserwację jakościową stosowaną np. „,do poznawania interakcji szkolnych" (Krüger 2004: 165). Analizowane działania nauczycielki służyły jedynie jako pole do próby dostrzeżenia i głębszego zrozumienia zjawiska ukrytej przemocy wobec uczniów na lekcji. Tekst jest próbą odpowiedzi na pytanie: Czy i w jaki sposób najmłodsi uczniowie mogą doświadczać ukrytej przemocy na lekcji matematyki?

\section{Historia jednej lekcji matematyki w klasie pierwszej szkoły podstawowej}

Oglądana lekcja okazała się bogatym materiałem do szukania i wskazywania sytuacji przemocowych, które zostały wygenerowane przez nauczycielkę nie zawsze świadomie. Jednak ich obecność może stanowić przyczynę przyszłych trudności ze zrozumieniem relacji matematycznych i w konsekwencji - z możliwością wykorzystania wiedzy matematycznej, a w końcu - niekorzystnych zdarzeń w życiu jednostki.

\section{Wyniki badań}

W trakcie lekcji zaskakująco często pojawiały się sytuacje, które można rozpatrywać jako przykłady przemocowych działań edukacyjnych, być może dlatego, że w szkole charakterystyczna jest istotna nierównowaga sił $\mathrm{w}$ relacji nauczyciel-uczeń. Ten pierwszy dysponuje środkami zastraszania (dyscyplinowania) uczniów, takimi jak: oceny, uwagi, 
wezwanie rodzica i inne. Uczeń, szczególnie w klasach początkowych, nie ma takich możliwości. Często nie potrafi się jeszcze przed nimi bronić, postrzegając je przez pryzmat własnej winy (złe zachowanie, niespełnienie obowiązków szkolnych itp.). Zauważone i opisane sytuacje stanowią w moim przekonaniu przykłady nadużywania tej przewagi.

\title{
Rytualy lekcyjne
}

Niemało sytuacji lekcyjnych ma charakter rytuału. Niektóre z nich mogą być oparte na działaniach przemocowych. Jako przykład można podać rozpoczynanie lekcji od „odpowiedniego" powitania. Nauczycielka na początku lekcji prosi, żeby wszystkie dzieci wstały i powiedziały „dzień dobry” (choć widziała się ze wszystkimi, ponieważ od kilkunastu minut ona i uczniowie są w tej klasie).

\author{
N: Dzień dobry. \\ UUU [półgłosem]: Dzień dobry. \\ N: Jeszcze raz. [głośniej i z naciskiem] Dzień dobry. \\ UUU [bardzo głośno]: Dzień-do-bry.
}

Takie zachowania uczestników lekcji są bardzo popularne i w potocznym mniemaniu służą kształceniu szacunku do innych osób. $Z$ obserwacji tej lekcji wynika również, że wejście do klasy ucznia dyżurnego w szkole $\mathrm{z}$ komunikatem do obwieszczenia nie powoduje konieczności wstania uczniów w klasie i przywitania się. W rozumieniu szkoły szacunek należy się przede wszystkim dorosłym, a najbardziej - nauczycielom. Trzeba również dodać, że poza szkołą ten sposób witania się nigdzie nie funkcjonuje. W szkole służy on raczej do zaznaczenia ważności nauczyciela. Uczeń otrzymuje sygnał, kto decyduje w klasie, kto wyznacza sposób zachowania i czyje oczekiwania należy spełniać. Doświadcza wówczas działania narzuconego przez instytucję - przemocy strukturalnej.

\section{Zaniechanie troski o uczniów}

Kolejny przykład zaliczam również do zjawiska przemocy strukturalnej. Po powitaniu lekcja zaczęła się od polecenia nakazującego usadowienie się dzieci na dywanie na dość małej powierzchni. Troska wyrażona przez nauczycielkę dotyczyła przede wszystkim komfortu osób dorosłych - studentek. Na dalszym etapie nauczycielka dążyła do utworzenia przez uczniów dużego i symetrycznego kółka, choć nie miało to znaczenia dla zaplanowanego ćwiczenia. Dzieci musiały się przepychać i przeciskać między sobą, szukając miejsca.

$\mathrm{N}$ : Bardzo proszę, siadamy na dywanie w kółeczku, tylko tak, żeby tam, eee, paniom na kolanach nie siadać.

N: Duże koło robimy, duże, duże, dzieciaki, koło na dywanie, eee, możecie siedzieć koło pań, to nie przeszkadza. 
Efekt nie spełnił oczekiwań nauczycielki, ponieważ dzieci nie chciały się zbytnio zbliżać do zajmujących częściowo dywan osób oglądających zajęcia.

N: Dzieci, wstańcie proszę, [głośno] wstańcie, wstańcie, wstańcie, zróbcie kółeczko, zróbcie kółeczko na dywanie, [głośniej] robimy kółko na dywanie tak, jakby pań nie było, duże kółko. Zamykamy kółeczko, zamykamy kółeczko. I teraz siadamy.

N: Troszkę się do tyłu przesuńcie, żebym ja mogła tu wejść na środek.

Ze strony nauczyciela nie padły słowa ,przepraszam” ani ,proszę”, które pojawiłyby się z pewnością w innym miejscu. W relacjach pozaszkolnych jest kulturowo oczywiste, że należy przeprosić, aby przejść przez zatłoczone miejsce. Lekcja okazuje się jednak geograficznie i czasowo punktem ograniczania przyjętych norm, przynajmniej w stosunku do dzieci. W tej samej klasie (jak zresztą w wielu innych) była powieszona kolorowa plansza z wypisanymi „,czarodziejskimi słowami”: proszę, przepraszam, dziękuję. Jednocześnie dzieci nabywają przekonania, że ich używanie obowiązuje raczej uczniów. Niedostatek nauczycielskich przykładów kulturalnego i przyjaznego zachowania wobec najmłodszych może skutkować nieprzestrzeganiem zasad zachowania przez dzieci wobec siebie nawzajem. Jeszcze dalej idąca konsekwencja to wytworzenie przekonania, że kulturalne zachowanie obowiązuje wobec jednostek silniejszych, ze słabszymi nie trzeba się za bardzo liczyć.

\section{Zaniechanie wyjaśnień nauczycielskich decyzji edukacyjnych}

Następny przykład jest związany z ignorowaniem przez nauczyciela potrzeby dzielenia się z uczniami celami działań. Podczas lekcji, siedząc ciasno obok siebie na dywanie, dzieci cicho rozmawiały. W tym czasie nauczycielka rozkładała na dywanie kolorowe szarfy, w środku których zbierała różne przedmioty, po pięć wewnątrz każdej szarfy. Nie podtrzymywała wówczas kontaktu z uczniami, nie wyjaśniała, do czego będą potrzebne przedmioty. Uczniowie zostali potraktowani przedmiotowo, sprowadzeni do roli obserwatorów nauczycielskiej aktywności, którzy nie muszą w niej uczestniczyć i nie muszą rozumieć jej celu. Być może tak odczytujący ten przekaz uczniowie również nie pytali o nic, co może świadczyć o powtarzających się tego typu sytuacjach. Ich uprzedmiotowienie zostało zaakceptowane jako naturalny stan lekcyjny.

\section{Ograniczanie uczniom prawa do uzasadniania, argumentowania i zadawania pytań}

Po rozłożeniu wszystkich szarf nauczycielka rozpoczęła zadawanie pytań.

N: Przyjrzyjcie się, proszę, tym wszystkim zbiorom, które leżą na dywanie ${ }^{1}$. Co one mają ze sobą wspólnego? Czy mają coś wspólnego?

\footnotetext{
1 Nauczycielka niepoprawnie się wyraziła, ponieważ zbiory to pojęcia umysłowe i nie mogą leżeć na dywanie. Mogą leżeć elementy zbiorów. Taki sposób kształcenia pojęcia „zbiór” może budować u uczniów przekonanie o tym, że zbiór jest tylko tam, gdzie pojawia się szarfa (por. Olecka, Semadeni 1984).
} 
U1: Jeden jest tylko z ptakami.

N.: Hmmm. Z ptakami, ale ja się pytam [z naciskiem], co one mają wspólnego, bo tamten jest tylko z ptakami, więc nie ma nic wspólnego z tymi pozostałymi? Kubuś.

U2: Nie.

U3 [niepewnie]: Wszystkie są... takie same... mają taki sam kolor.

$\mathrm{N}$ [powątpiewająco]: Wszystkie są tego samego koloru? A które są tego samego koloru?

U3 [nieśmiało]: Szyszki i ptaki (rysunki rzeczywiście są w kolorystyce szarobrązowej).

$\mathrm{N}$ [z powątpiewaniem]: No, tak mniej więcej..., ale ja cały czas twierdzę, że wszystkie te zbiory mają ze sobą coś wspólnego.

Brakowało dyskusji dzieci, argumentowania, przekonywania się nawzajem, jedyna poprawna interpretacja należała do nauczycielki. Doświadczenia tego typu sprawiają, że najmłodsi uczniowie oduczają się korzystania z własnych koncepcji matematycznych i podporządkowują się przemocy symbolicznej, również w sytuacjach, które nie mają uzasadnienia poznawczego.

U4: Jest po pięć.

N [zadowolona]: A, świetnie, Natasza zauważyła. Policzcie, ile jest kółek.

Podany tu przykład przemocy symbolicznej nie jest odosobniony w polskich szkołach. Dorota Klus-Stańska opisuje wiele lekcji matematyki, w których dominuje monolog nauczyciela (Klus-Stańska 2000). Również Małgorzata Żytko przytacza fragment lekcji matematyki w klasie trzeciej jako przykład braku zachęcania uczniów do wyjaśniania i argumentowania na rzecz sprawnego reagowania na wypowiedzi nauczyciela. Jest to również przykład dominacji ,sformalizowanego schematu komunikacyjnego zarządzanego przez nauczyciela" (Żytko 2014: 339). Kolejny fragment lekcji odnosi się również do przytoczonych spostrzeżeń, nakładając dodatkowo warstwę nauczycielskich przekonań o poziomie myślenia uczniów.

\section{Infantylizowanie treści matematycznych}

Wskazane dzieci po kolei liczyły elementy kolejnych zbiorów na dywanie. Pomimo znajomości przez większość uczniów liczb większych niż 10 byli oni po raz kolejny zmuszani do przeliczania w zakresie 5. Inny sposób infantylizowania był widoczny w poleceniu personifikowania liczb.

$\mathrm{N}$ : Chciałabym, żebyście ułożyli bajkę o tych liczbach.

UUU: [trochę zdezorientowane cicho rozmawiają].

$\mathrm{N}$ [przekrzykuje szumek w klasie]: O czym mogłyby rozmawiać ze sobą liczby, które spotkały się w bajkowym królestwie?

UUU: [nie odpowiadaja]. 
$\mathrm{N}:$ Iga, jaką ty masz propozycję?

U12: [mówi coś cicho].

$\mathrm{N}$ : Znaczy, co mogą mówić?

UUU [nadal coś cicho mówią między sobą].

$\mathrm{N}$ [zniecierpliwiona klaszcze dwukrotnie, żeby uciszyć klasę]: Ćśś.

N: Ola mogłaby powiedzieć: „Ja nazywam się...” [zawiesza głos].

UU [cicho]: Dwa.

N: Ola mogłaby powiedzieć: „Ja nazywam się dwa”. Co jeszcze Ola mogłaby powiedzieć, gdyby mogła mówić, tak jak w bajkowym królestwie wszystko mogłoby się zdarzyć? Co ona jeszcze mogłaby powiedzieć, na przykład do Hani?

Używanie na przemian pojęcia liczby i imion dzieci tworzy pewien chaos poznawczy. Zupełnie inne cechy przynależą Hani i inne liczbie dwa. O ile ta ostatnia ma cechę parzystości, ponieważ dzieli się przez dwa, to przekładanie tej własności na Hanię jest absurdem. Przytoczone zachowania nauczyciela postrzegam jako wyraz odtwarzania kulturowych znaczeń dotyczących nadawania niewielkiej wartości wiedzy i myśleniu uczniów, a także ich możliwościom poznawczym.

\section{Ograniczanie aktywności i zainteresowań uczniów}

Kolejny przejaw przemocy strukturalnej sygnalizuje konieczność podporządkowania się dzieci przyjętej przez nauczyciela organizacji lekcji oraz narzuconym przez niego formom zachowania. Przywołam jeszcze raz moment, w którym uczniowie, nie mając przez kilka minut zajęcia, zaczęli cicho rozmawiać, siedząc obok siebie na dywanie. Jedyny kontakt, jaki nawiązała wówczas nauczycielka, polegał na ich upomnieniu, co sygnalizowało brak akceptacji dla takiej aktywności w czasie lekcji, nawet wówczas, gdy uczniowie nie mają innych zadań do wykonania.

$\mathrm{N}$ [nadal rozkładając przedmioty]: Dzieci, ale już nie gadamy.

W innym momencie dwie dziewczynki zainteresowały się przedmiotami leżącymi w jednej z szarf. Reakcja nauczycielki była natychmiastowa:

N: Dziewczynki, nie ruszamy tych kółek.

Nauczycielka nie zapytała o powód zainteresowania się kółkami, a nawet zabroniła ich dotykać. Być może zaniepokoiła się brakiem uwagi uczennic, które na chwilę przestały śledzić odpowiedzi innych uczniów. Pomimo wykazanego przez nie zainteresowania odebrała im prawo nawet do krótkiej aktywności inspirowanej osobistym zaciekawieniem. Skutkiem doświadczania takich sytuacji może być również przekonanie uczniów o niepodzielnej władzy nauczyciela nad całą przestrzenią klasy. 


\section{Publiczne rozpatrywanie blędu ucznia}

Przemocowy charakter następnego przykładu wyjaśnia koncepcja ukrytego programu komponentu przemocy symbolicznej. Opisana sytuacja jest elementem powtarzalnego lekcyjnego doświadczenia wywierającego niekorzystny wpływ na ucznia (Kruszewski 1993: 112).

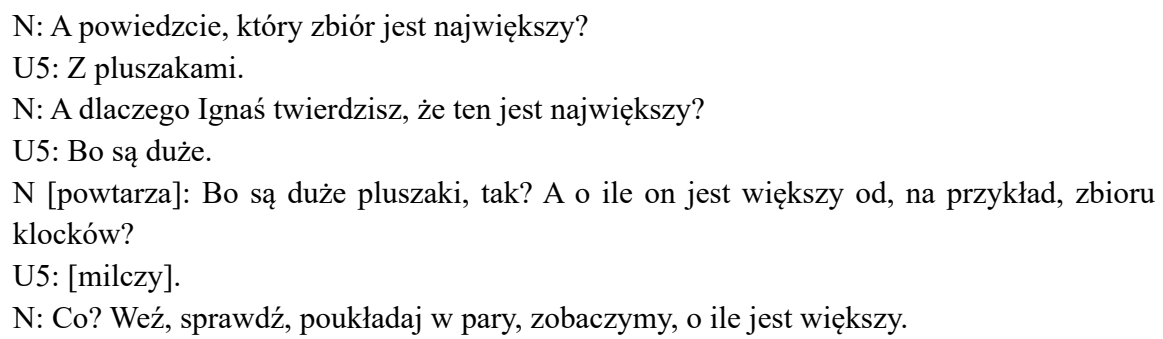

Chłopiec układał przedmioty w pary, reszta klasy czekała, choć pozostali uczniowie dobrze znali poprawną odpowiedź. Nauczycielka zapytała jeszcze raz, o ile jest większy, a on nieśmiało stwierdził, że jest tyle samo. Nauczycielka ponownie spytała go głośno, zmuszając do ponownego thumaczenia się z niepoprawnej odpowiedzi.

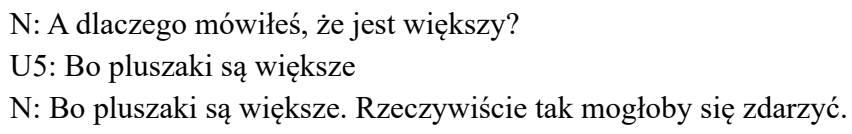

Logika porównywania zbiorów zaprezentowana przez tego ucznia jest naturalna dla przedoperacyjnego etapu rozwoju poznawczego. Jednak zamiast dyskretnej pomocy w zdobywaniu doświadczeń budowania pojęcia liczby nastąpiła publiczna analiza jego odpowiedzi i zwrócenie uwagi całej klasy na ,niedostatek” wiedzy ucznia. Sytuacja była z pewnością niezbyt komfortowa dla chłopca, a inni uczyli się, że błąd może skutkować znalezieniem się w trudnym położeniu, więc nadawano mu pejoratywne zabarwienie.

\section{Wygaszanie aktywności dzieci na lekcji}

Naturalna u dzieci chęć aktywności może być blokowana w sytuacji, gdy nauczyciel nie dba o tę potrzebę, a co gorsza, wykorzystuje ją do sygnalizowania władzy nad uczniami. Praca równym frontem na lekcji matematyki jest najczęściej związana z koniecznością wskazywania uczniów, którym nauczyciel udziela głosu lub pozwala na zaprezentowanie na tablicy rozwiązania. Jeszcze więcej chętnych (proszących podniesieniem ręki do góry) pojawia się, gdy niezbędny jest udział małej liczby uczniów, którzy będą mieć określoną „rolę” w ćwiczeniu (trzymać pomoce, wykonywać doświadczenie itp.). Ponieważ można przyjąć, że każde z dzieci ma „kwalifikacje” do wykonania tej czynności, wybór 
tego, a nie innego dziecka może być źródłem zawodu dla pozostałych. Brak wyjaśnienia kryterium wyboru i autorytarna postawa nauczyciela, jak w poniższym przykładzie, nie ułatwiają dzieciom akceptacji nauczycielskiej decyzji i mogą być rodzajem opresji psychicznej (kary).

$\mathrm{N}$ : A ja poproszę teraz Jasia...

UUU [trzymają ręce w górze]: Ja, ja...

N [zdecydowanie]: Opuśćcie ręce. Jasia, Mateusza, Hanię, Olę i Anetę.

Niektórzy uczniowie krzywią się i są wyraźnie niezadowoleni. Konieczność podporządkowania się wskazaniom nauczyciela jest, pomimo doświadczanego uczucia zawodu, przykładem przyjmowania przez uczniów działania władzy jako obowiązującego schematu szkolnego i uznawania go za naturalny.

\section{Zarzadzanie czasem poznawczym}

Kolejny przykład przedstawia nieuświadamiane przez uczniów, ale narzucone przez nauczyciela akty przemocy strukturalnej. Jednym z przejawów nauczycielskiego ograniczania rozwoju poznawczego dzieci jest odmowa prośbie ucznia, który wykonał już swoje zadanie i pragnie zająć się kolejnymi. Ilustruje tę sytuację przykład, gdy w pewnym momencie lekcji podczas układania z patyczków trójkątów uczeń głośniej zapytał:

U15: Mogę ułożyć jeszcze więcej?

$\mathrm{N}$ : Wszystko w swoim czasie.

Uczniom nie wolno również manipulować przedmiotami według swoich pomysłów. Kiedy kilkoro z nich po spełnieniu polecenia podczas dalszej pracy próbowało układać patyczki na swój sposób, nauczycielka zakończyła tę aktywność. Likwidowała spontaniczne działania poznawcze uczniów bez nadania im jakiejkolwiek wartości.

\section{Narzucanie przez nauczyciela wlasnego sposobu rozumienia}

W wielu przypadkach nauczycielka podążała jedynie za swoimi znaczeniami matematycznymi, dostrzegając i akceptując te wypowiedzi uczniów, które odpowiadały jej rozumieniu. W pewnym momencie pięcioro wybranych dzieci otrzymało kartki z cyframi 1-5. Pozostali uczniowie mieli ustawić te dzieci w prawidłowej kolejności. Domyślnym kryterium, zresztą świetnie odczytanym przez uczniów, były liczby. Za chwilę okazało się jednak, że nauczycielka miała na myśli liczby porządkowe, a jeszcze za chwilę, że liczby nie są ważne. Odnalezienie się dziecka w tej gonitwie narzucanych kontekstów myślenia jest problematyczne i nie buduje samodzielnej oceny, jaka sytuacja wymaga określonego sposobu porządkowania. Konieczność nieustannego śledzenia myśli nauczyciela zagłuszała u dzieci tworzenie własnych znaczeń. 
$\mathrm{N}$ : No dobrze, a teraz powiedzcie mi... gdybyśmy mieli sprawdzić, kto jest pierwszy... teraz od tej strony [wskazuje przeciwny koniec rzędu pięciorga dzieci].

UUU [cicho]: Piąty...

$\mathrm{N}$ : Które dziecko jest teraz pierwsze...

U10: Mateusz [chłopiec z numerem 5]

$\mathrm{N}$ [potwierdza]: Mateusz, chociaż ma liczbę pięć. Bo ja teraz liczę [zawiesza głos]

U11: Od pięciu.

U12: Od tyłu.

N: Od drugiej strony, bo to tylko zapisane cyferki są.

Liczenie od tyłu, jak słusznie myślały dzieci, jest liczeniem od pięciu do jednego. Nauczycielka nie próbowała zrozumieć trudności dzieci. Kontynuowała natomiast pogadankę, oczekując podporządkowania się uczniowskiego myślenia własnym propozycjom.

N: No to policzmy teraz od tyłu. Który jest Mateusz?

UUU: Piąty, pierwszy.

$\mathrm{N}$ [z naciskiem]: Z tej strony liczymy, to jest który? [wskazuje kolejno palcem]

UUU [chórem]: Pierwszy, drugi.

N: Trzecia, czwarta [dzieci milkną i kończy sama] piąta.

W przedstawionych nauczycielskich aktach językowych ujawniła się przemoc symboliczna wobec uczniów. Nauczycielka narzucała nie tylko strategie liczenia, ale również osobisty kontekst poznawczy, utrudniając dzieciom rozumienie sytuacji matematycznej.

\section{Odpowiadanie za dzieci}

Kulturowo przekazywane są również przekonania nauczycieli dotyczące pomocy uczniowi. W potocznym mniemaniu dobry nauczyciel natychmiast reaguje na niezadowalającą, jego zdaniem, wypowiedź ucznia. Ogranicza to znacznie możliwość podejmowania dziecięcego namysłu, zastanawiania się i budowania nowej wiedzy. W opisanym przykładzie pokazano sytuację, w której brak natychmiastowej reakcji na polecenia nauczycielki uruchamia jej kompulsywne starania, aby pomóc uczniom. Jednak prowadzą one do jeszcze większego zamętu poznawczego dzieci. Pomimo tych zabiegów uczniowie nie potrafili wpisać się w oczekiwania nauczycielki, która niecierpliwie podpowiadała i naprowadzała.

U13: Że Hania jest starsza od niej. [Hania trzyma liczbę 3]

$\mathrm{N}$ : O ile?

U13: O jeden

$\mathrm{N}$ : Jak starsza to musi być o... jeden dzień, rok, miesiąc..., godzinę.

UU: Nie...

N: To ona teraz mówi, ile dzieci mają lat, tak? Można tak powiedzieć? [odpowiada sama]:

W bajkowym królestwie wszystko można.

(...) 
N: A gdyby nie chciały mówić, kto jest starszy, a kto młodszy. I te liczby nie pokazują teraz, ile mają lat, a na przykład pokazują... hmm..., ile... hmm..., w ile kropek się zamieniają. UUU: [cicho mówią do siebie].

$\mathrm{N}$ : To, co by mogły powiedzieć... eee, Amelka, co ty mogłabyś powiedzieć do Mateusza?

U14: Że ja jestem młodsza od...

$\mathrm{N}$ [przerywa]: Nie... ja powiedziałam, że zamieniacie się w kropki i dwa pokazuje, w ile kropek możesz się zamienić.

U14: Cztery.

$\mathrm{N}$ : No to, co powiesz, on może się zamienić... [zawiesza głos].

UUU: W sześć.

$\mathrm{N}$ : Będzie ciebie pięć, to o ile będzie więcej tych kropek?

UUU [chórem]: O jeden.

W przedstawionej tu sytuacji trudno doszukać się realizowania celu nastawionego na ćwiczenie umiejętności liczenia (choć być może taki właśnie cel dostrzegała nauczycielka). Dla uczniów była to raczej gra w zgadywanie kryterium akceptowania ich wypowiedzi.

\section{Ograniczanie prawa do manipulowania przedmiotami}

Obserwacja lekcji wskazuje, że nauczycielka akceptowała manipulowanie przedmiotami jedynie wówczas, gdy kierowała każdym krokiem uczniów. Ich samodzielna aktywność w tym zakresie była określana jako „zabawa” i nie przedstawiała dla niej wartości. Uczniowie budowali wówczas przekonanie, że ich samodzielne próby kontaktu z klockami nie mogą być źródłem wiedzy, a dobra zabawa wyklucza uczenie się.

N: Zostawcie wszystko na dywanie, później będziecie się mogli tym pobawić.

Bliżej nieokreślona przyszłość, kiedy manipulowanie będzie dozwolone, budzi niepokój uczniów, że obietnica zostanie zapomniana, co wskazywałoby na brak zainteresowania ich potrzebami. Dyskredytowanie zabawy jako naturalnej dla tego wieku i efektywnej strategii budowania wiedzy matematycznej ma charakter ukrytej przemocy wobec uczniów. Chęć zabawy nabiera odcienia pejoratywnego jako zachowania niezbyt odpowiedniego i infantylnego.

\section{Wnioski i zakończenie}

Przedstawione sytuacje edukacyjne na lekcji matematyki w klasie pierwszej wydają się $\mathrm{z}$ pozoru naturalne dla tego etapu edukacji. Istotności nabiera jednak odpowiedź na pytanie, czy mogą one negatywnie wpływać na uczniów, czy mają charakter przemocowy. $\mathrm{Z}$ ich analizy wynika, że można wskazać niekorzystne konsekwencje dla rozwoju dzieci, pojawiające się przede wszystkim w obszarze społecznym i poznawczym. 


\section{Naruszanie godności osobistej uczniów}

Charakterystyczną cechą przemocy jest naruszenie godności osobistej. Z perspektywy rozwoju społecznego nauczycielka kreuje sytuacje przemocowe, ograniczające szacunek do dziecka, przez nierespektowanie jego potrzeb oraz specyfiki rozwojowej. Uczeń jest wikłany w przemocowy związek interpersonalny, w którym według określenia Cezarego Kurkowskiego ofiara jest zależna od sprawcy i ma osłabioną zdolność do obrony emocjonalnej (Kurkowski 2005: 1056). Na przykład konieczność analizowania błędu w obecności całej klasy może zwracać uwagę dzieci na niedostatki ucznia, a jego krytyczne ocenianie przez nauczyciela może być naśladowane przez innych uczniów. Zmuszanie dziecka do swego rodzaju publicznej wiwisekcji, przed którą nie może się bronić, narusza jego poczucie godności.

Z perspektywy rozwoju poznawczego zadania zbyt łatwe dla uczniów tłumią rozbudzanie zainteresowania matematyką i ograniczają rozwój myślenia matematycznego. Najmłodsi uczniowie są zmuszeni do pewnej gry z nauczycielem, którą trudno im wygrać. Wyznaczanie przez nauczyciela sposobów rozumienia poleceń, pojęć czy sytuacji edukacyjnych oraz brak możliwości spontanicznych i osobistych wypowiedzi uczniów skazuje wielu z nich na zaniechanie takiej aktywności. Częste niepowodzenia ucznia w poprawnym odczytaniu nauczycielskich znaczeń może w konsekwencji obniżać poczucie własnej wartości oraz zaburzać kontrolę nad wiedzą matematyczną. Kilka lat temu popularne były badania Johna Hattiego Visible Learning for Teachers: Maximizing Impact on Learning. Choć należy do nich podchodzić ostrożnie ze względu na niejasności metodologiczne, wyniki były interesujące. Analizował on 50000 badań i ponad 800 zbiorczych prac naukowych, które wskazują, że samoocena uczniów najwyżej koreluje z poprawą efektów nauczania matematyki. Działania nauczyciela obniżające poczucie wartości i mocy sprawczej uczniów zdecydowanie niekorzystnie wpływają na ich matematyczne (i nie tylko) funkcjonowanie (Hattie 2012).

\section{Nierespektowanie praw dziecka}

Jednym z najważniejszych praw budujących tożsamość jednostki jest prawo do szacunku, o którym pisał już prawie 100 lat temu Janusz Korczak. Postulował prawo do szacunku dla niewiedzy dzieci, ich niepowodzeń, cech i własności czy dla czasu bieżącego (Korczak 1948). W przestrzeni klasowej dostrzegane są jednak sytuacje, gdy nauczyciel nie akceptuje jakiegokolwiek odstępstwa od założonego zachowania dziecka. Lucyna Kopciewicz twierdzi, że nauczyciele wczesnej edukacji na podstawie potocznego rozumienia procesu uczenia się tworzą katalog pożądanych cech swoich uczniów. Inność dziecka albo podlega pozornej akceptacji, albo jest eliminowana ze względu na - ich zdaniem - dobro jednostki (Kopciewicz 2012: 106, 109). Poziom rozwoju poznawczego dziecka wyznacza jego słabość, jeśli nie odpowiada oczekiwaniom szkoły. Również dziecięcość jako immanentna cecha najmłodszych uczniów, charakteryzująca się wysokim poziomem ciekawości, 
chęci eksploracji, dzielenia się swoimi myślami, nie jest respektowana. Podkreślane są natomiast oczekiwania nauczycielki. Wielokrotnie pojawiały się na lekcji sformułowania typu: ,ja tak teraz liczę”, ,ja teraz chcę” czy „nie chcę, żebyście...”. Nie towarzyszyły im żadne argumenty wyjaśniające dzieciom sens jej wypowiedzi. Sposób wypowiadania poleceń był kategoryczny i nie pozostawiał wątpliwości co do braku akceptacji dyskutowania. Nie była przewidziana również możliwość zmiany rodzaju pracy przez ucznia w wypadku, gdy jego kompetencje matematyczne były na dużo wyższym poziomie niż te wymagane w zadaniu. Takie działania nauczycielki należy postrzegać jako brak szacunku dla rozwoju dziecka. Również sztywne i nieadekwatne do potrzeb dziecka zarządzanie czasem, jak przerywanie pracy wówczas, gdy dzieci są właśnie nią zainteresowane, nosi znamiona wykorzystywania nauczycielskiej przewagi nad uczniem. Przytoczone wyniki badań oczywiście nie wyczerpują możliwości rozpoznawania zjawiska nauczycielskiej przemocy wobec najmłodszych uczniów na lekcji matematyki. Jednak nawet tak niewielki fragment budzi niepokój o zakres, częstotliwość i siłę doświadczeń przemocowych już w początkowych klasach szkolnych.

\section{Literatura}

Bałachowicz J. (2017), Szkoła jako przestrzeń budowania przyszłości. W: J. Bałachowicz, A. Korwin-Szymanowska, E. Lewandowska, A. Witkowska-Tomaszewska, Zrozumieć uczenie się-zmienić wczesna edukację. Warszawa, Wydawnictwo APS.

Boaler J. (2016), Mathematical mindsets. Unleashing Students' POTENTIAL Through Creative Math, Inspiring Messages and INNOVATIVE TEACHING. San Francisco, Jossey-Bass.

Bourdieu P., Wacquant L.J.D. (2001), Zaproszenie do socjologii refleksyjnej. Warszawa, Oficyna Naukowa.

Dąbrowski M. (2008), Pozwólmy dzieciom myśleć. Warszawa, CKE.

Dąbrowski M. (2009), Edukacyjna codzienność klasy trzeciej. W: M. Dagiel, M. Żytko (red.), Badanie umiejętności podstawowych uczniów trzecich klas szkoły podstawowej. Nauczyciel ksztatcenia zintegrowanego 2008 - wiele różnych światów? Warszawa, CKE.

Falkiewicz-Szult M. (2007), Przemoc symboliczna w przedszkolu. Kraków, Oficyna Wydawnicza „Impuls".

Hattie J. (2012), Visible Learning for Teachers: Maximizing Impact on Learning. Abingdon-New York, Routledge.

Kalinowska A. (2010), Pozwólmy dzieciom działać. Warszawa, CKE.

Klus-Stańska (2000), Konstruowanie wiedzy w szkole. Olsztyn, Wydawnictwo Uniwersytetu Warmińsko-Mazurskiego.

Klus-Stańska D., Kalinowska A. (2004), Rozwijanie myślenia matematycznego najmłodszych uczniów. Warszawa, Wydawnictwo Akademickie „Żak”.

Klus-Stańska D., Nowicka M. (2014), Sensy i bezsensy w edukacji wczesnoszkolnej. Gdańsk, Harmonia Universalis.

Koczara A. (1997), Przemoc w domu rodzinnym. „Problemy Rodziny”, 1-2.

Konecko K.T. (200), Studia z metodologii badań jakościowych. Teoria ugruntowana. Warszawa, Wydawnictwo Naukowe PWN. 
Kopciewicz L. (2012), Równa szkoła. Matematyka, władza i pole wytwarzania kultury. Warszawa, Difin.

Korczak J. (1948), Prawo dziecka do szacunku. Warszawa, Spółdzielnia Wydawnicza.

Krug E.G., Dahlberg L.L., Mercy J.A., Zwi A.B., Lozano R. (2002), World report on violence and health. Geneva, World Health Organization. https://apps.who.int/iris/bitstream/handle/10665/42495/9241545615_eng.pdf;jsessionid=5A16F5F82D170EAAF6DAEA81A9CF $\mathrm{B} 43 \mathrm{C}$ ? sequence $=1,10.11 .2019$.

Krüger H.H. (2004), Metody badań w pedagogice. Gdańsk, GWP.

Kruszewski K. (1993), 45 minut. Prawie cała historia pewnej lekcji. Warszawa, Wydawnictwo Naukowe PWN.

Kurkowski C. (2005), Przemoc $w$ rodzinie na tle innych rodzajów przemocy. W: J. Pilch (red.), Encyklopedia pedagogiczna XXI wieku. T. IV. Warszawa, Wydawnictwo Akademickie „Żak”.

Kwieciński Z. (1995), Socjopatologia edukacji. Olecko, Mazurska Wszechnica Nauczycielska.

Lundin M., Wesslund T. (2016), Global study on violence against children - in and around schools. Research report summary, save the children. Sweden. Rädda Barnen. https://resourcecentre.savethechildren.net/node/10323/pdf/rb_globalstudy_vac_161115.pdf, 7.11.2019.

Olecka A., Semadeni Z. (1984), Pojęcie zbioru. W: Z. Semadeni, Nauczanie początkowe matematyki. T. 2. Warszawa, WSiP.

O’Neil C. (2017), Broń matematycznej zagłady. Jak algorytmy zwiększają nierówności społeczne i zagrażaja demokracji. Warszawa, Wydawnictwo Naukowe PWN.

Rode D. (2010), Psychologiczne uwarunkowania przemocy w rodzinie. Charakterystyka sprawców. Katowice, Wydawnictwo Uniwersytetu Śląśkiego.

Ruge J. (2018), On epistemological violence in mathematics education research - An exemplary study in the Journal of Mathematics Teacher Education. „The Mathematics Enthusiast”, 15(1-2). https://scholarworks.umt.edu/tme/vol15/iss1/17, 1.11.2019.

Sawisz A. (1989), Szkoła a system społeczny. Warszawa, WSiP.

Sfard A. (2008), Thinking as Communicating: Human Development, the Growth of Discourses, and Mathematizing. Cambridge, Cambridge University Press.

Stake R.E. (2009), Jakościowe studium przypadku. W: N.K. Denzin, Y.S. Lincoln (red.), Metody badań jakościowych. T. 1. Warszawa, Wydawnictwo Naukowe PWN.

Żytko M. (2014), Edukacja językowa w szkole - między dążeniem do formalizacji schematu a refleksja nad uczestnictwem w zdarzeniach komunikacyjnych. W: D. Klus-Stańska, (Anty)edukacja wczesnoszkolna. Kraków, Oficyna Wydawnicza „Impuls”. 